\title{
Determination of Motivation of 5th Grade Students Living in Rural and Urban Environments towards Science Learning and their Attitudes towards Science-technology Course ${ }^{1}$
}

\author{
İsmail Kenar ${ }^{1}$, Mücahit Köse ${ }^{1}$, Halil İbrahim Demir ${ }^{1}$ \\ ${ }^{1}$ Dumlupınar Universtiy, Faculty of Education, Kütahya, Turkey \\ Correspondence: Assist. Prof. Dr. İsmail Kenar, Dumlupınar Universtiy, Faculty of Education, Kütahya, Turkey.
}

Received: March 18, 2016 Accepted: March 29, 2016 Online Published: April 18, 2016

doi:10.11114/jets.v4i7.1561

URL: http://dx.doi.org/10.11114/jets.v4i7.1561

\begin{abstract}
In this research, determination of motivation of 5th grade students living in rural and urban environments towards science learning and their attitudes towards science-technology course is aimed. This research is conducted based on descriptive survey model. Samples are selected through teleological model in accordance with the aim of this research. Samples are formed of 8615 th grade students from a total of 13 schools in rural and urban environments within the provincial borders of Kütahya. "Scale of Towards Science Learning" developed by Dede and Yaman (2008) and "Scale of Attitudes towards Science and Technology Course for 4th and 5th Grade Elementary School Students" developed by Kenar and Balcı (2012) are utilized as data collection tools.

It is identified as a result of this research that it is female students of the rural environment and male students of the urban environment who have better motivation towards science learning. It is determined that students living in rural environments whose families belong to high income group have better motivation towards science learning, while there is no significant difference depending on income groups in the case of students living in urban environments. It is concluded that attitudes of female students compared to male students towards science and technology course are more positive in both environments. No significant difference by family income status is found for students living in rural environment, while in the case of urban environments, an increase in family income status ends up with an increase in their attitudes towards science and technology course.
\end{abstract}

Keywords: science and technology, motivation, attitude, rural-urban, student

\section{Introduction}

Science education may be considered as a major pillar for our age of science and technology. Nowadays, in parallel with development of science and technology throughout the world, new teaching and learning methods are being sought. In alignment with this new quest, the link between students' living environment and their level of attitudes and motivation should be identified as a reference to science education and teaching. In our country, as the definition of our science and technology teaching program which aims to create science-literate individuals suggests "Science and technology literacy is an outcome of science-related skills, values, attitudes, comprehension and knowledge which are prerequisites to queries and researches, problem solving, critical thinking and decision making, life-time learning and maintaining the sense of wonder towards external world" (MEB, 2005). Attitude is a phenomenon that is learned, leading individual's manners and causing partiality during decision making process (Ülgen, 1996).

Considering students' positive or negative attitudes towards sciences are formed beginning from the elementary school, it may be predicated that impact of these attitudes acquired during this period will remarkably influence their subsequent educational background.

There are two major things qualifying attitudes: They are long-lasting and constitute cognitive, emotional and behavioral patterns. Scaling attitudes and determining individuals' level of attitudes on a relevant object or a case is desired (Erkuş, 2003). Attitudes are not innate, there are many factors affecting their formation. Since children's

\footnotetext{
${ }^{1}$ This research was presented at International Conference on Innovation and Challenges in Education 2013 (CICE 2013), 26 - 28 April 2013 - Kütahya, Turkey.
} 
attitudes are formed in their early ages, elementary school period plays a critical role for them in terms of developing positive attitudes towards science (Jewett, 1996). As a result of the false elucidations by community, most of the students find science and technology course difficult and complex. Thus students' tendency to science and technology and their prospective academic successes are negatively affected. For this reason, students should become reconciled to and love science, and they should be able to develop positive attitudes (Harlen, 1990).

When a student develops negative attitudes towards any course, it does not want to attend, do its homework, and may search for tickets of nonattendance. If it feels pressure against doing its homework, it contradicts itself (Ülgen, 1995).

In a research by Baykul (1990), it is identified that students in Turkey tend to loosen their attitudes towards sciences, beginning from their 5th year in elementary school. It is also stated that attitudes of primary education teachers, contents of science books and science teachers towards course influence student's attitudes towards science.

In another undergraduate academic research, attitudes of 1 st grade students who study in the division of primary education towards sciences and science teaching is examined, and it is determined that their attitudes are positive in general. It is found that students from urban regions have more positive attitudes compared to rural regions, and also it is seen that the more students have science courses during their secondary education the more they have positive attitudes (Türkmen, 2002).

Çepni, Ayas, Johnson and Turgut (1996) define science as "a creative and critical examination of daily-life natural events and ending up with specific generalizations and principles". As a number of recent researches suggest, students' motivation towards science learning is the pillar of their understanding of sciences. It is identified in a research conducted among elementary school students that students with a higher motivation do have teachers who are "sciential, and direct, enforce and encourage their students for independent action" (Midgley, C.M., Feldlaufer, H., and Accles, J.S., 1989). Deliberately developing skills in order to enrich and cement life is a critical step for the sake of utilization of individual capacity entirely. Each individual has a strength of a life-time learning and productivity. And education is the most significant investment for increasing individuals' interests and motivation towards developing their life skills (Godsmith, 2000).

Motivation which is of the factors contributing to individual differences is defined in general as "intrinsic condition causing reflection of human behaviors and leading them" (Ertan, 2006). Dede and Yaman (2008) defines Martin and Briggs motivation as a comprehensive structure that contains intrinsic and extrinsic conditions affecting creation, maintenance and control of a behavior.

Motivation is a booster of students' success, leading them work hard in school and learn (Martin, 2001). Students' creativity is considered as an important and effective factor on their learning styles, academic successes and such (Kuyper, van der Werf and Lubbers, 2000; Wolters, 1999). The more motivation of a student is high, the more the teaching program is effective. If motivation factor is neglected in teaching environments, teaching will fail or be not as much as required (Spitzer, 1996). As researches (Napier and Riley, 1985; Pintrich et al, 1993; Wolters, 1999; Kuyper et al, 2000; Wolters and Rosenthal, 2000; Özkan, 2003) suggest, motivation plays an important role in science teaching, students' success in sciences, their conceptual changes, critical thinking and development of science skills. Terrell $\mathrm{H}$. Bell (1921-1996) says "There are three things to remember about education: motivation, motivation and motivation", highlighting how important motivation is for education (in Dede and Yaman, 2008).

In recent years, some of the researches conducted on science teaching issues have focused on students' individual differences and its connection with their science success. It is essential to acknowledge students' learning methods, and their attitudes and motivation towards science, in order to well-plan science teaching. Individuals differ in terms of their learning methods, motivation towards the course and their attitudes, and these differences affect their science successes (Azizoğlu and Çetin, 2009). For Hendrickson (1997), motivation and attitude are the best predictors of students' success to be referred. There are many academic researches indicating academic success increases by motivation upheaval (Patrick, Kpangban and Chibueze, 2007; Shih and Gamon, 2001; Singh, Granville and Dike, 2002).

There are researches on elementary and secondary school students' attitudes and motivation, but there are only limited amount of researches (Kozcu, Çakır, Şenler, and Göçmen Taşkın, 2007) aiming to reveal elementary school students' (from urban and rural environments) attitudes and motivation towards science and technology class and sciences. Attitudes of students from villages, boroughs and city center of Muğla towards science and technology course are analyzed, concluding there is no difference between students by the settlement they live.

For the researches in which motivation towards science learning is examined by gender variant, number of researches indicating females are better motivated (Yaman and Öner, 2006; Yılmaz and Huyugüzel Çavaş, 2007; Demir, Öztürk, and Dökme, 2012; Uzun and Keleş, 2010; Güvercin, 2008) and the ones demonstrating no difference between female and male students by gender variant (Azizoğlu and Çetin, 2009; Yenice, Saydam and Telli, 2012) is higher than those 
showing male students are better motivated (Debacker and Nelson, 2001). In conclusion, there are different findings in terms of motivation by gender variant. And for the researches on attitudes towards science and technology, number of researches indicating females have better attitudes (Gürkan and Gökçe, 2000) and the ones demonstrating male students have better attitudes (Akbudak, 2005; George, 2000; Serin and Muhammedzadeh, 2008; Jovanic and King, 1998; Osborne, Simon and Collins, 2003) is higher than those showing no difference by gender variant (Alkan, 2006; Kaya and Büyük, 2011).

It is concluded in a research by Demir, Öztürk and Dökme (2012) to determine students' motivation towards science learning by family income status variant that there is no difference, and there is a positive relationship between their motivation towards science learning and their academic successes. In the case of socio-economic status variant, Alkan (2006) concludes that students with a better socio-economic status have better attitudes towards science and technology course; however, Kozcu, Çakır, Şenler and Göçmen Taşkın (2007) find no difference in terms of students' attitudes by this variant. Osborne, Simon and Collins (2003) found in their research dealing with attitudes towards science out that attitudes towards science are not affected by socio-economic status.

According to some of the researches conducted (Dede and Yaman, 2007; İnel Ekici, Kaya and Mutlu, 2014), students' motivation towards science learning decreases if class level increases. 5th grade was included in elementary school in Turkey until 2013, however it is the first year of middle school education, as stated by law (4+4+4 education model). Until 5th grade primary school teachers teach science courses, but after 5th grade, it is science and technology teachers who teach. Since 5th grade students are studying the first year of middle school, which is a transitional period, their motivation and attitudes towards science learning constitute a basis for their subsequent education.

\subsection{Aim of the Research}

In this research, determination of motivation of 5th grade students living in rural and urban environments towards science learning and their attitudes towards science-technology course is aimed. Sub problems determined based on the general aim are as follows:

a. What is the level of 5th grade students' motivation towards science learning and their attitudes towards science-technology course?

b. Does 5th grade students' motivation towards science learning and their attitudes towards science-technology course differ by settlement variant (rural or urban)?

c. Is there a significant difference between female and male students' motivation towards science learning and attitudes towards science-technology course by gender variant?

d. Does 5th grade students' motivation towards science learning and their attitudes towards science-technology course differ by family income status?

\section{Method}

\section{$2.1 \mathrm{Model}$}

In this research we used relational screening method from descriptive survey model. Relational screening models are models aiming to determine presence and/or degree of covariance between two or more variants. In this model, aim of the descriptions is to identify differentiations between individuals, objects, etc rather than finding measurements of the existing according to specific standards. Relationships found through screening method may not be interpreted as a true cause and effect relationship; however, if a state within a variant is determined then they may provide useful findings for predicting the other (Karasar, 2003). Moreover, researchers want to provide an explanation of how allocation of universe is by variants (Fraenkel and Wallen, 2006). In this research, we examined students' motivation towards science learning and attitudes towards science and technology course by their settlements (rural-urban), gender and family income status.

\subsection{Study Group}

Samples are chosen using stratified teleological sampling method from systematic sampling model. Stratified teleological sampling including of individuals who lives in the universe and have different characteristics in line with aim of the research (Büyüköztürk, Kılıç Çakmak, Akgün, Karadeniz and Demirel, 2008). Sampling of this research is formed of 5th grade students from elementary schools (central and rural) affiliated to Provincial Directorate for National Education, Kütahya. Study group includes 406 students (197 females, 209 males) from 10 schools in rural environments, 455 students (227 females, 228 males) from 3 schools in urban environments, which is 861 th grade students from 13 schools in total. 


\subsection{Data Collection Tools}

"Scale of Towards Science Learning" developed by Dede and Yaman (2008) and "Scale of Attitudes Towards Science and Technology Course for 4th and 5th Grade Elementary School Students" developed by Kenar and Balc1 (2012) are utilized as data collection tools.

\subsubsection{Scale of Motivation towards Science Learning}

In order to determine motivation of 5th grade students towards science learning studying in rural and urban areas, likert-type scale is used (Dede and Yaman, 2008). Answer columns of the items in the scale are organized as "5.Strongly Agree", "4.Agree", "3.Neutral", "2.Disagree", "1.Strongly Disagree". This scale contains 23 questions and 5 factors. Collected data is analyzed using SPSS. In order to demonstrate allocation of students by gender, family income status and settlement, frequency values are used. Factors are respectively factor 1: motivation towards researching; factor 2: motivation towards performance; factor 3: motivation towards communication; factor 4: motivation towards collaboratively studying; and factor 5: motivation towards attendance. Cronbach alpha reliability coefficient is calculated as .80 (Dede and Yaman, 2008). In this research, Cronbach alpha reliability coefficient of the scale is calculated as .82 .

2.3.2 Scale of Attitudes of Elementary School 4th and 5th Grade Students towards Science and Technology Course

Assessment tool designed to determine students' attitudes towards science and technology course is a 5-point likert-type scale. Answer columns of the items in the scale are organized as "5. Strongly Agree", "4. Agree", "3. Neutral", "2. Disagree", "1. Strongly Disagree".

First factor: Interest: means anxiety, displeasure, reluctance and indifference against science and technology course;

Second factor: Appreciation: means feelings while studying for and talking about science and technology course;

Third factor: Continuing studying: means time spent on science and technology course and how student benefited from it. Cronbach alpha reliability coefficient is calculated as .83 while developing the scale (Dede and Yaman, 2012). In this research, Cronbach alpha reliability coefficient of the scale is calculated as .81 .

\subsubsection{Transactions}

Permissions required for implementation of scales are acquired from Kütahya Provincial Directorate of National Education. In order to allow students respond to scale items, appropriate environment is created, enough time is given for responses and data is collected.

\subsection{Analysis of Data}

When implementation process is completed, SPSS is used for analysis of the collected data. During analysis, collected data is categorized by settlement (rural or urban), gender (female or male) and family income status (intermediate, high, higher). For the analysis of the categorized data, independent t-test, one-way anova, post hoc test and correlation tests are used.

\section{Findings}

In this section, findings on research variants are included. In this research, settlement, family income status and gender variants are analyzed in terms of their impacts on students' (similar class level) motivation towards science learning and their attitudes towards science-technology course, and findings are tabularly interpreted.

3.1 Findings on Motivation of 5th Grade Students Living in Rural and Urban Environments towards Science Learning

Table 1. Students' Motivation towards Science Learning

\begin{tabular}{lllll}
\hline Dimensions of motivation & $\begin{array}{l}\text { number of } \\
\text { questions }\end{array}$ & $\overline{\mathbf{X}}$ & standard deviation \\
\hline Motivation Towards Researching & 6 & 4.16 & .74 \\
Motivation Towards Performance & 5 & 4.25 & .93 \\
Motivation Towards Communication & 5 & 4.20 & .74 \\
Motivation Towards Collaboratively & 4 & 3.96 & .77 \\
Studying & & & .71 \\
Motivation Towards Attendance & 3 & 4.43 & .51 \\
Motivation in General & 23 & 4.19 & \\
\hline
\end{tabular}

According to Table 1, it is identified that values are good on "Motivation Towards Researching" and "Motivation Towards Collaboratively Studying", and values are very good on "Motivation Towards Performance", "Motivation Towards Communication" and "Motivation Towards Attendance". In terms of scores of Motivation in General, values are also good. 
Table 2. Independent t-test results of students' motivation towards science learning who live in urban and rural areas

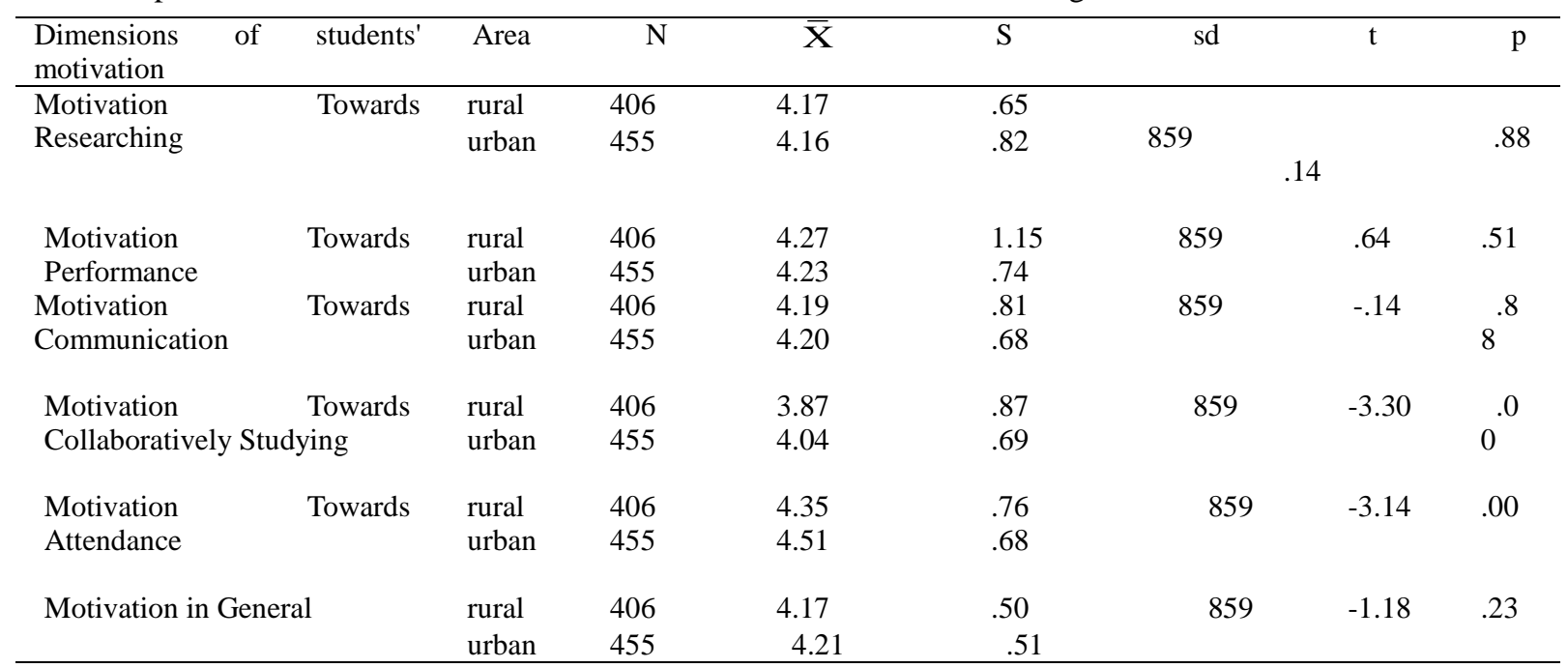

As it is indicated in Table 2, $p<.05$ means that there is a significant difference between students studying in rural and urban areas in terms of 4 th dimension of motivation $(t=-3.30 ; p=.00)$. Negative $t$ value in Table 2 indicates that in 4 th dimension, motivation of 5 th grade students, who study in urban areas, towards science learning is significantly higher than those in rural areas. Similarly in 5th dimension, there is a significant difference between students who study in rural and urban areas $(\mathrm{t}=-3.14 ; \mathrm{p}<.05 ; \mathrm{p}=.00)$. Negative $\mathrm{t}$ value in Table 2 indicates that in 5 th dimension, motivation of 5th grade students, who live in urban areas, towards science learning is higher than those in rural areas. Analysis results are examined in terms of dimensions and there is no significant difference between rural-area and urban-area students' general motivation, however mean scores of 5th grade students studying in urban areas turns out to be slightly higher than those in rural areas $\left(\mathrm{p}=.23 ; \mathrm{p}>.05 ; \overline{\mathrm{X}}_{\text {urban }}(4.21)>\overline{\mathrm{X}}_{\text {rural }}(4.17)\right)$. As it is demonstrated in Table 2, $\mathrm{p}>.05$ means $(\mathrm{p}=.88 ; \mathrm{p}=.51 ; \mathrm{p}=.88)$ there is no significant difference between rural-area and urban-area students in terms of 1 st, 2 nd and 3rd dimensions.

Table 3. Independent t-test results of students' motivation towards science learning who live in rural areas by gender variant

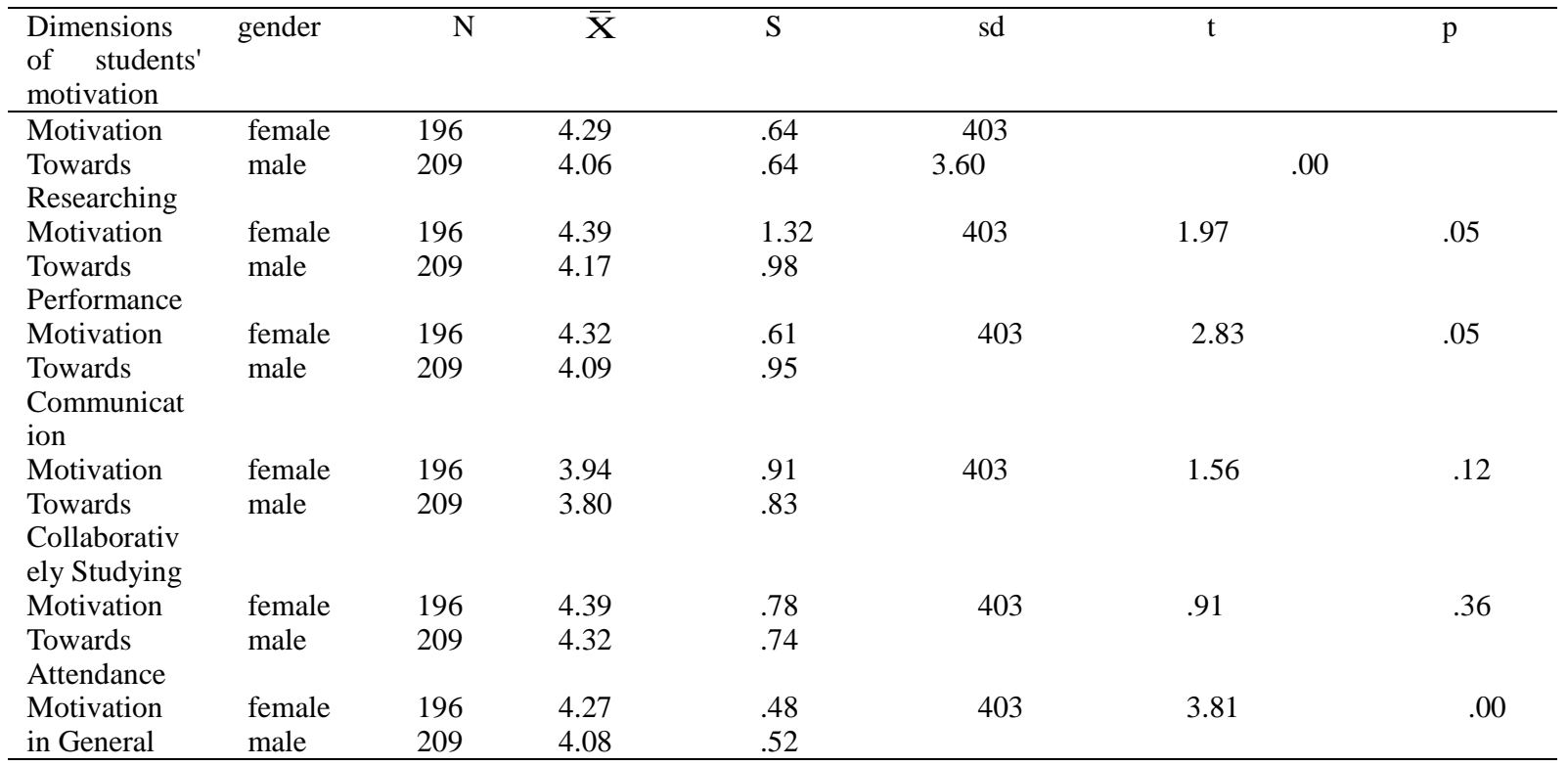

As it is indicated in Table 3, p <.05 means that there is a significant difference between male and female students in terms of 1 st dimension by gender variant $(t=3.60 ; p=.00)$. According to the table, positive $t$-value and mean scores of $\overline{\mathrm{X}}_{\text {female }}(4.29)>\overline{\mathrm{X}}_{\text {male }}(4.06)$ demonstrate that 5 th grade female students' motivation towards science learning in rural areas in the 1 st dimension is higher that males. Similarly, $\mathrm{p}<.05$ means that there is a significant difference between male and female students in terms of motivation in general $(\mathrm{t}=3.81 ; \mathrm{p}=.00)$. It is identified according to Table 3 that positive $t$-value and mean scores of $\bar{X}_{\text {female }}(4.27)>\bar{X}_{\text {male }}(4.08)$ demonstrate 5 th grade female students' motivation towards science learning in rural areas in the 1 st dimension is higher that males. When $2 \mathrm{nd}, 3 \mathrm{rd}$, 4th and 5 th dimensions 
are evaluated, $\mathrm{p}>.05(\mathrm{p}=.05 ; \mathrm{p}=.05 ; \mathrm{p}=.12 ; \mathrm{p}=.36)$ means that there is no significant difference among rural-area students by gender variant.

Table 4. Independent t-test results of students' motivation towards science learning who live in urban areas by gender variant

\begin{tabular}{|c|c|c|c|c|c|c|c|}
\hline $\begin{array}{l}\text { Dimensions of } \\
\text { students' } \\
\text { motivation }\end{array}$ & gender & $\mathrm{N}$ & $\overline{\mathrm{X}}$ & $\mathrm{S}$ & $\mathrm{sd}$ & $\mathrm{t}$ & $\mathrm{p}$ \\
\hline Motivation & female & 227 & 4.04 & .64 & 452 & \multirow{3}{*}{.02} & \\
\hline Towards & male & 228 & 4.24 & .64 & -2.42 & & \\
\hline Researching & & & & & & & \\
\hline Motivation & female & 227 & 4.23 & 1.32 & 452 & -.33 & .75 \\
\hline $\begin{array}{l}\text { Towards } \\
\text { Performance }\end{array}$ & male & 228 & 4.25 & .98 & & & \\
\hline Motivation & female & 227 & 4.15 & .61 & 452 & -1.42 & .16 \\
\hline $\begin{array}{l}\text { Towards } \\
\text { Communicati } \\
\text { on }\end{array}$ & male & 228 & 4.25 & .95 & & & \\
\hline Motivation & female & 227 & 3.98 & .91 & 452 & -1.75 & .08 \\
\hline $\begin{array}{l}\text { Towards } \\
\text { Collaborativel } \\
\text { y Studying }\end{array}$ & male & 228 & 4.10 & .83 & & & \\
\hline Motivation & female & 227 & 4.45 & .78 & 452 & -1.83 & .07 \\
\hline $\begin{array}{l}\text { Towards } \\
\text { Attendance }\end{array}$ & male & 228 & 4.57 & .74 & & & \\
\hline Motivation in & female & 227 & 4.15 & .49 & 452 & -2.27 & .02 \\
\hline General & male & 228 & 4.26 & .52 & & & \\
\hline
\end{tabular}

As it is indicated in Table 4, p $<.05$ means that there is a significant difference between male and female students in terms of $1 \mathrm{st}$ dimension by gender variant $(\mathrm{t}=-2.47 ; \mathrm{p}=.02)$. Negative $\mathrm{t}$ value indicates that in $1 \mathrm{st}$ dimension, motivation of 5 th grade male students, who live in urban areas, towards science learning is higher than females. Similarly, $\mathrm{p}<.05$ means that there is a significant difference between male and female students in terms of motivation in general $(\mathrm{t}=-2.27 ; \mathrm{p}=.02)$. Negative $\mathrm{t}$ value indicates that motivation of 5 th grade male students, who live in urban areas, towards science learning is higher than females. When 2nd, 3rd, 4th and 5th dimensions are evaluated, $\mathrm{p}>.05(\mathrm{p}$ $=.75 ; \mathrm{p}=.16 ; \mathrm{p}=.08 ; \mathrm{p}=.07)$ means that there is no significant difference among urban-area students by gender variant.

Table 5. One-way anova test results of students' motivation towards science learning who live in rural areas by family income status

\begin{tabular}{|c|c|c|c|c|c|c|}
\hline $\begin{array}{l}\text { Dimensions of } \\
\text { students' } \\
\text { motivation }\end{array}$ & Income status & $\mathrm{N}$ & $\bar{X}$ & $\mathrm{~S}$ & $\mathrm{sd}$ & $\mathrm{p}$ \\
\hline Motivation & intermediate & 174 & 4.09 & .71 & & \\
\hline Towards & high & 188 & 4.24 & .59 & 403 & .0 \\
\hline Researching & higher & 44 & 4.17 & .58 & 9 & \\
\hline Motivation & intermediate & 174 & 4.16 & .74 & & \\
\hline Towards & High & 188 & 4.40 & 1.49 & 403 & .1 \\
\hline Performance & Higher & 44 & 4.15 & .76 & 1 & \\
\hline Motivation & intermediate & 174 & 4.20 & .97 & & \\
\hline Towards & high & 188 & 4.24 & .63 & 403 & . \\
\hline $\begin{array}{l}\text { Communicati } \\
\text { on }\end{array}$ & higher & 44 & 4.02 & .80 & 29 & \\
\hline Motivation & intermediate & 174 & 3.79 & .88 & & \\
\hline Towards & high & 188 & 3.97 & .87 & 403 & . \\
\hline $\begin{array}{l}\text { Collaborative } \\
\text { ly Studying }\end{array}$ & higher & 44 & 3.76 & .79 & 11 & \\
\hline Motivation & intermediate & 174 & 4.26 & .86 & & \\
\hline Towards & high & 188 & 4.46 & .65 & 403 & \\
\hline Attendance & higher & 44 & 4.28 & .73 & .04 & \\
\hline Motivation in & intermediate & 174 & 4.10 & .48 & & \\
\hline \multirow[t]{3}{*}{ General } & high & 188 & 4.26 & .53 & 403 & \\
\hline & Higher & & & & .00 & \\
\hline & 4.08 & .47 & & & & \\
\hline
\end{tabular}

In Table 5, since students' motivation towards science learning by family income status variant is $\mathrm{p}<.05(\mathrm{p}=.04 ; \mathrm{p}$ 
$<.05 ; \overline{\mathrm{X}}_{\text {high }}(4.46)>\overline{\mathrm{X}}_{\text {higher }}(4.28)>\overline{\mathrm{X}}_{\text {intermediate }}(4.26)$, a significant difference is found, and significance level of this difference is determined to be in support of students whose family income status is high. When mean scores of 5 th dimension (motivation towards attendance) are evaluated, it is understood that 5th grade students' attendance towards science courses, activities and class discussions is at a significant level and is in support of students whose family income status is high. Since students' motivation in general by family income status variant is $\mathrm{p}<.05(\mathrm{p}=.00 ; \mathrm{p}<.05$; $\overline{\mathrm{X}}_{\text {high }}(4.26)>\overline{\mathrm{X}}_{\text {intermediate }}(4.10)>\overline{\mathrm{X}}_{\text {higher }}$ (4.08), a significant difference is found, and this difference is determined to be in support of students whose family income status is high. When 1st, 2nd, 3rd and 4th dimensions are evaluated, $\mathrm{p}>.05(\mathrm{p}=.09 ; \mathrm{p}=.11 ; \mathrm{p}=.29 ; \mathrm{p}=.11)$ means that there is no significant difference among rural-area students by family income status variant in terms of their motivation.

Table 6. One-way anova test results of students' motivation towards science learning who live in urban areas by family income status

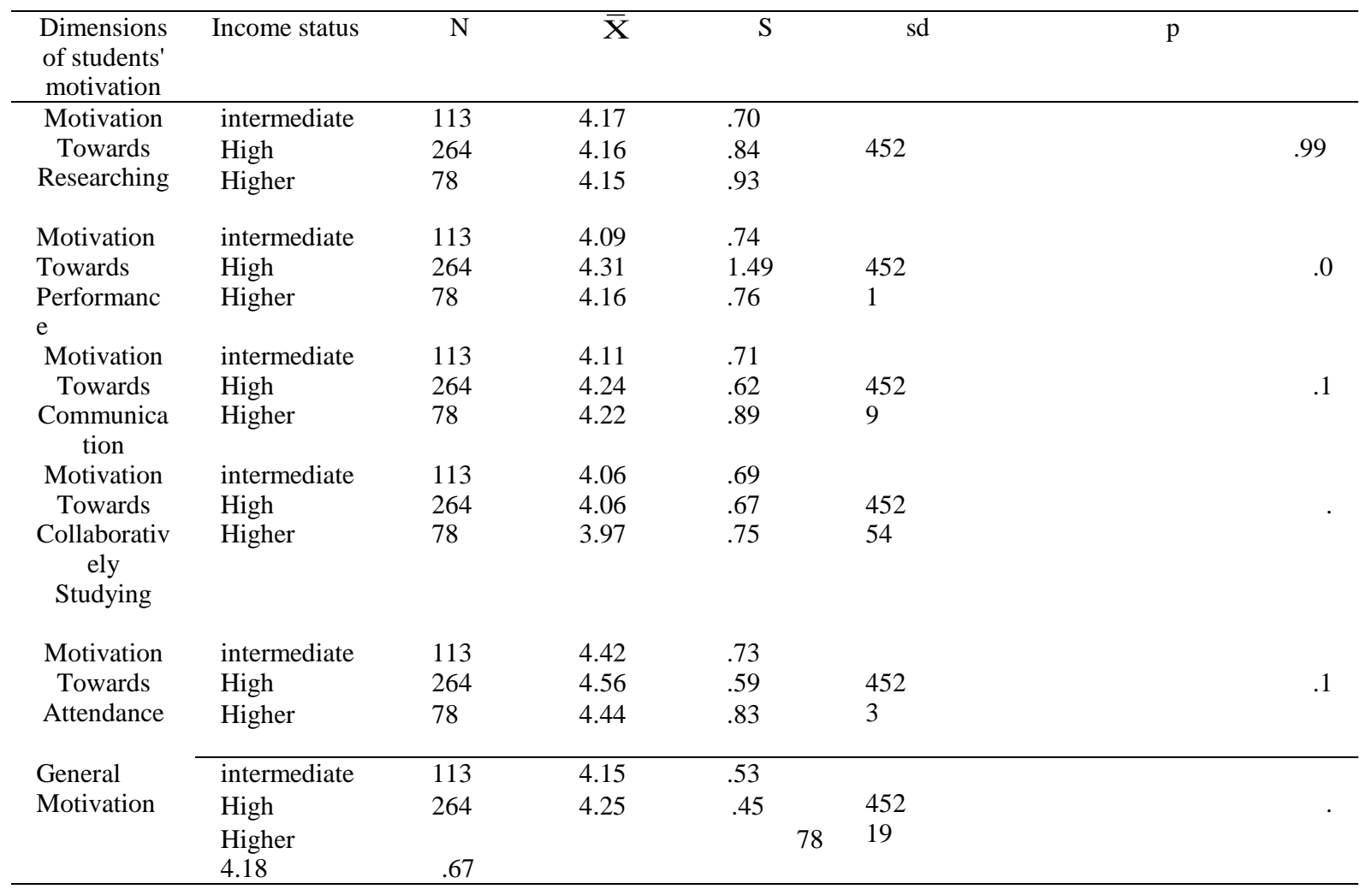

In Table 6, since students' motivation towards science learning by family income status variant is $\mathrm{p}<.05(\mathrm{p}=.01$; $\mathrm{p}$ $<.05 ; \bar{X}$ high (4.31)> $\bar{X}$ higher (4.16) > $\bar{X}$ intermediate (4.09) in 2nd dimension, a significant difference is found, and significance level of this difference is determined to be in support of students whose family income status is high. Since motivation in general is $\mathrm{p}>.05(\mathrm{p}=.19 ; \mathrm{p}=.99 ; \mathrm{p}=.19 ; \mathrm{p}=.54)$ in $1 \mathrm{st}$, 3rd, 4 th and 5th dimensions, there is no significant difference among urban-area students by family income status variant in terms of their motivation towards science learning.

3.2 Findings on Attitudes of 5th Grade Students Living in Rural and Urban Environments towards Science and Technology Course

Table 7. Attitudes of 5th grade students living in rural and urban environments towards science and technology course

\begin{tabular}{|c|c|c|c|}
\hline Attitudes and dimensions & $\begin{array}{l}\text { number } \\
\text { questions }\end{array}$ & $\overline{\mathrm{X}}$ & $\begin{array}{c}\text { standard } \\
\text { deviation }\end{array}$ \\
\hline Interest & 6 & 4.07 & .83 \\
\hline Appreciation & 3 & 4.14 & .77 \\
\hline Continuing studying & 3 & 4.02 & .85 \\
\hline Attitude in general & 12 & 4.08 & .66 \\
\hline
\end{tabular}

When Table 7 is examined, taking students' mean attitude scores into consideration, it may be concluded that students are at a good level in all dimensions that constitute attitudes and attitudes in general. 
Table 8. Independent t-test results of students' attitudes towards science and technology course who live in urban and rural areas

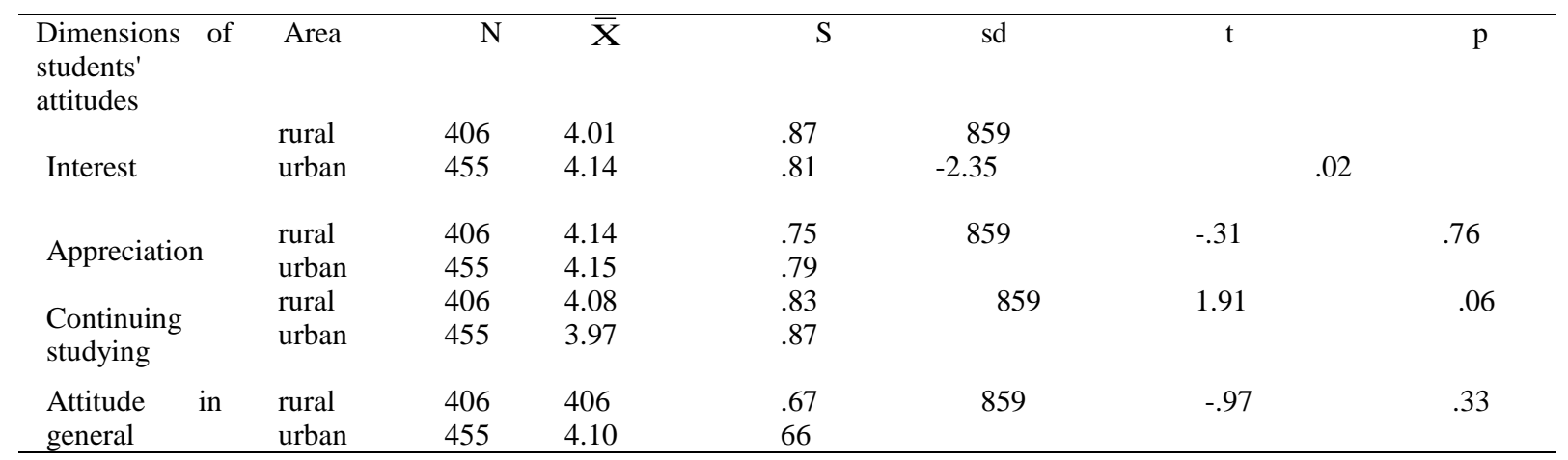

According to Table $8, \mathrm{p}<.05$ means that there is a significant difference between students living in urban and rural areas in 1 st dimension $(t=-2.35 ; p=.02)$. Considering negative $t$-value and mean scores of $\bar{X}_{\text {urban }}(4,14)>\overline{\mathrm{X}}_{\text {rural }}$ $(4,01)$ in Table 8 , attitudes of 5 th grade students who live in urban areas towards science and technology course in the 1st dimension are higher than those in rural areas. For 2nd, 3rd dimensions, and attitudes towards science and technology course in general, $\mathrm{p}>.05(\mathrm{p}=.76 ; \mathrm{p}=.06 ; \mathrm{p}=.33)$ means there is no significant difference between students living in rural and urban areas.

Table 9. Independent t-test results of students' attitudes towards science and technology who live in rural areas by gender variant

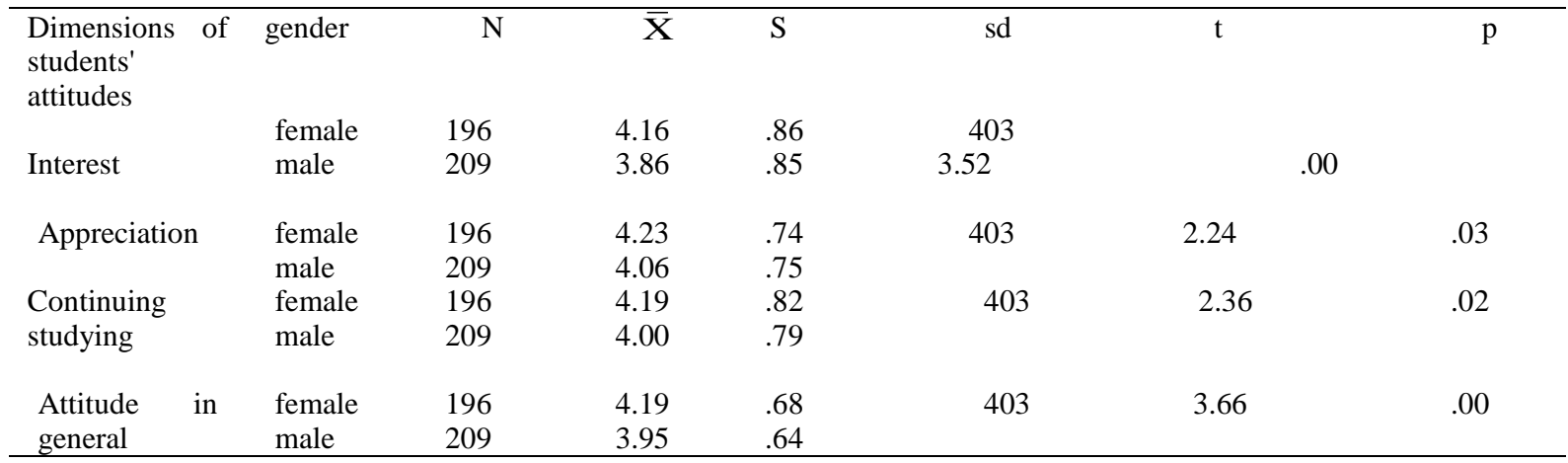

According to Table 9, p <.05 means that there is a significant difference between female and male students in terms of 1st, 2nd, 3rd dimensions and attitudes in general, and this difference is determined to be in support of female students in terms of all dimensions and attitudes in general $((\mathrm{t}=3.52 ; \mathrm{p}=.00) ;(\mathrm{t}=2.24 ; \mathrm{p}=.03) ;(\mathrm{t}=2.36 ; \mathrm{p}=.02) ;(\mathrm{t}=3.66 ; \mathrm{p}$ $=.00)$ ). It is identified according to the table that positive t-value and mean scores of $\mathrm{X}_{\text {female }}(4.16)>\mathrm{X}_{\text {male }}(3.86)$; $\overline{\mathrm{X}}_{\text {female }}(4.23)>\overline{\mathrm{X}}_{\text {male }}$ (4.06); $\overline{\mathrm{X}}_{\text {female }}(14.19)>\overline{\mathrm{X}}_{\text {male }}$ (4.00); $\overline{\mathrm{X}}_{\text {female }}$ (4.19) $>\overline{\mathrm{X}}_{\text {male }}$ (3.95) demonstrate female students in rural areas are better than male students in terms of attitudes and dimensions constituting attitudes.

Table 10. Independent t-test results of students' attitudes towards science and technology who live in urban areas by gender variant

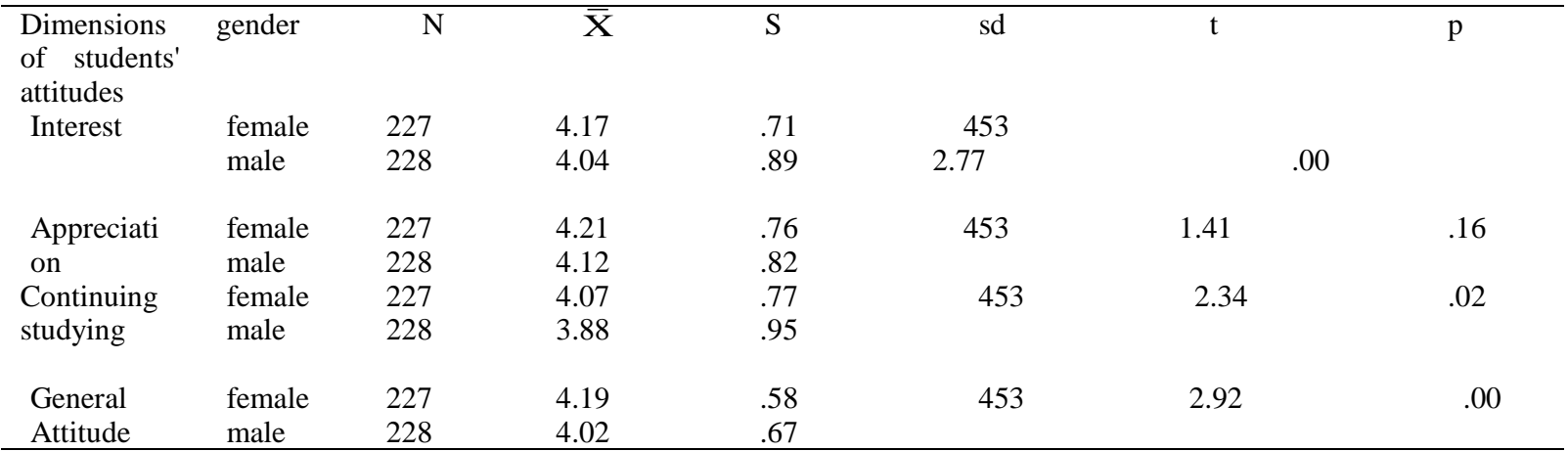

In Table 10, in terms of attitudes in general and 1st and 3rd dimensions constituting the attitudes, $\mathrm{p}<.05$ means that there is a significant difference between female and male students $((\mathrm{t}=2.77 ; \mathrm{p}=.00),((\mathrm{t}=2.34 ; \mathrm{p}=.02),((\mathrm{t}=2.92 ; \mathrm{p}$ $=.00)$ ). T-values are positive, which means that in terms of 1st and 3rd dimension and attitudes in general, attitudes of 5th grade female students in urban areas towards science and technology course are at a better level compared to males. 
However in 2 nd dimension, $p>.05(p=.16)$ means that there is no significant difference among students in urban areas by gender variant.

Table 11. One-way anova test results of students' attitudes towards science and technology course who live in rural areas by family income status variant

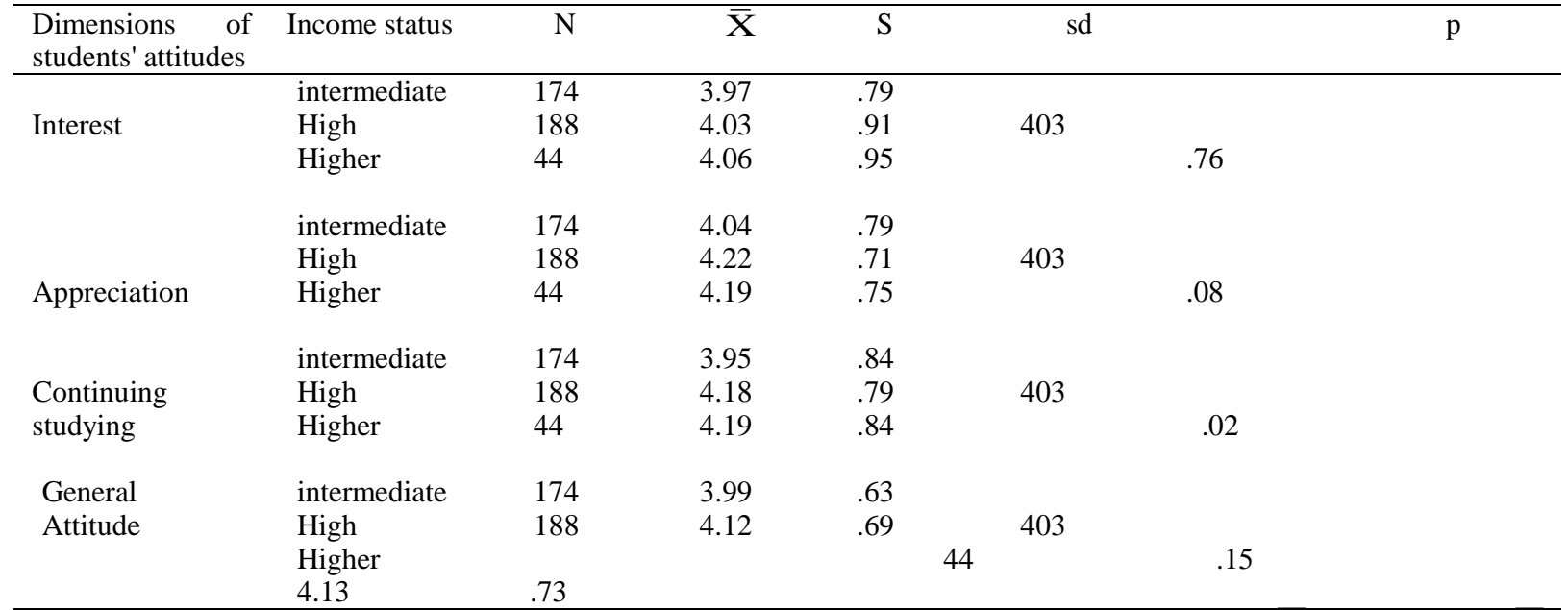

According to Table 11, since students' attitudes are $\mathrm{p}<.05$ by family income status $\left(\mathrm{p}=.02 ; \mathrm{X}_{\text {higher }}(4.19)>\mathrm{X}_{\text {high }}\right.$ $(4.18)>\mathrm{X}_{\text {intermediate }}(3.95)$ ), a significant difference is found between students, and this difference is determined to be in support of students whose family income status is higher and high. 3rd dimension (continuing studying) showed significant difference between students with a higher and high family income status and those with a intermediate family income status. For this reason, 5th grade rural-area students' attitudes towards time spent on science and technology course and how they benefited from it is found to be in support of students whose family income status is higher and high. When 1 st and 2 nd dimensions are evaluated, $\mathrm{p}>.05(\mathrm{p}=.76 ; \mathrm{p}=.08 ; \mathrm{p}=.15)$ means that there is no significant difference between attitudes rural-area students by family income status variant.

Table 12. One-way anova test results of students' attitudes towards science and technology course who live in urban areas by family income status variant

\begin{tabular}{|c|c|c|c|c|c|c|}
\hline $\begin{array}{l}\text { Dimensions of of } \\
\text { students' attitudes }\end{array}$ & Income status & $\mathrm{N}$ & $\bar{x}$ & S & sd & $\mathrm{p}$ \\
\hline \multirow{4}{*}{ Interest } & Intermediate & 113 & 4.02 & .84 & & \\
\hline & High & 264 & 4.20 & .74 & 452 & \\
\hline & Higher & 78 & 4.12 & .93 & .14 & \\
\hline & intermediate & 113 & 3.98 & .84 & & \\
\hline \multirow{3}{*}{ Appreciation } & High & 264 & 4.20 & .76 & 452 & \\
\hline & Higher & 78 & 4.25 & .78 & .03 & \\
\hline & intermediate & 113 & 3.84 & .94 & & \\
\hline \multirow{2}{*}{$\begin{array}{l}\text { Continuing } \\
\text { studying }\end{array}$} & High & 264 & 3.98 & .82 & 452 & \\
\hline & Higher & 78 & 3.97 & .91 & .07 & \\
\hline General & intermediate & 113 & 3.97 & .72 & & \\
\hline \multirow{2}{*}{ Attitude } & High & 264 & 4.15 & .62 & 452 & \\
\hline & Higher & & & & .04 & \\
\hline
\end{tabular}

When Table 12 is evaluated, students' attitudes bu family income variant in 2nd dimension is $\mathrm{p}<.05\left(\mathrm{p}=.03 ; \mathrm{X}_{\text {higher }}\right.$ (4.25) $>\bar{X}_{\text {high }}(4.20)>\bar{X}_{\text {intermediate }}$ (3.98)), a significant difference is identified. Considering mean significance levels, it is found to be in support of students whose family income status is higher. As a conclusion, attitudes of 5th grade students in urban areas towards their feelings on science and technology course are found to be in support of students whose family income status is higher. Since general attitudes of students by family income status are $\mathrm{p}<.05(\mathrm{p}=.04 ; \mathrm{p}$ $<.05 ; \overline{\mathrm{X}}_{\text {higher }}(4.16)>\overline{\mathrm{X}}_{\text {high }}(4.15)>\overline{\mathrm{X}}_{\text {intermediate }}$ (3.97)), a significant difference is determined. This difference is found to be in support of students whose family income status is higher. Since it is $p>.05(p=.14 ; p=.07)$ for 2 dimensions constituting the attitude, no significant difference is determined between attitudes of students living in urban areas. 


\section{Results and Discussion}

In this research, 5th grade students' motivation towards science learning and their attitudes towards sciences in rural and urban areas are analyzed according to a number of variants. As a result of this research, students' motivation in general is found to be at a high level. In general, no significant difference is found between 5th grade students' motivation towards science learning in rural and urban areas, however in terms of dimensions of "motivation towards collaboratively studying" and "motivation towards attendance", students living in urban areas are found to be better when compared to the ones in rural areas. It is found out that 5th grade students' motivation towards attendance living in urban areas is at a better level compared to the ones in rural areas.

It is determined that 5th grade female students' motivation towards science learning in rural areas is better than males, while male students' motivation towards science learning in urban areas is better than females. This result derived from urban areas is in parallel with research results of Debacker and Nelson (2001). Male students' motivation towards researching is found better than females. Different results are acquired in researches relevant to the motivation of students by gender variant. The result indicating that females are better than males in terms of motivation towards science learning in rural areas is in parallel with the literature (Yaman and Öner, 2006; Yılmaz, Huyugüzel Çavaş, 2007; Güvercin, 2008; Uzun and Keleş 2010; Azizoğlu Çetin, 2009). Similarly, it is identified that female students' motivation towards researching in rural areas is better than males. However there is no research on causes of this result.

A significant difference is determined between students' motivation in rural areas by family income status categorized as intermediate, high, and higher. This difference is found to be in support of students with a high family income status rather than those with an intermediate or higher family income status. This same difference is also identified in 5th dimension of motivation (motivation towards attendance). As a result, it is understood that 5th grade students' attendance towards science courses, activities and class discussions is at a significant level and is in support of students whose family income status is high. In attitudes in general, a significant difference is found in students motivation considering family income status, and this difference is found to be in support of students with a high family income status (should be support with literature, or is invalid).

It is concluded that there is no significant difference between 5th grade students' motivation by family income status variant living in urban areas. This result is share similarity with other results by Demir, Öztürk and Dökme (2012). Only in 2nd dimension of motivation (motivation towards performance), a significant difference is identified between students with a high family income status and students with a intermediate and higher family income status. This difference is found to be in support of students with a high family income status. This dimension includes items for assessment and appreciation of performance, and extrinsic motivational perceptions.

In this research, when findings acquired in relation with the attitudes towards science and technology course are evaluated;

5th grade students' motivation in general is found to be at a high level. It is concluded that no significant difference is found when 5th grade students' attitudes towards science learning in urban and rural areas are compared, while a significant difference is found between students living in rural and urban areas in terms of 3rd dimension of the attitude (continuing studying), in support of those living in rural areas.

A significant difference is found between female and male students in support of females within all dimensions including 5th grade students' general attitudes towards science learning and interest, appreciation and continuing researching in rural areas by gender variant. It may be concluded from research results that female students' attitudes towards science learning is better than males in rural areas.

In urban areas, female students' attitudes towards science learning are better than males. In sub dimensions, a significant difference is found between female and male students in support of females in terms of 1st (interest) and 3rd (continuing researching). It may be said that female students' attitudes towards science learning is better in both rural and urban areas. This result is in parallel with Gürkan and Gökçe (2000), but differs from results of Jovanic and King (1998), and Osborne, Simon and Collins (2003).

Considering family income status, no significant difference is found between students' attitudes towards science learning in rural areas. This result is in parallel with

Simon and Collins (2003). Considering sub dimensions constituting attitudes, a significant difference is found in students' attitudes by their family income status in terms of 3rd dimension (continuing researching). This difference is found to be in support of students with a higher family income status. 5th grade rural-area students' attitudes towards time spent on science and technology course and how they benefited from it is found to be in support of students whose family income status is higher.

In urban areas, there is a significant difference between students in terms of their general attitudes towards science 
learning and dimension of appreciation. This difference is found to be in support of students with a higher family income status. As a conclusion, attitudes of 5th grade students in urban areas towards their feelings on science and technology course are found to be in support of students whose family income status is higher. Students' attitudes towards science learning get better, if family income status gets better. These results are in parallel with Alkan (2006).

It is stated in the completed researches that there is a positive correlation between motivation and attitudes towards science and technology, and students' academic success on science courses. Motivation of students who are pushed to be science- and technology-literate individuals and their attitudes towards science and technology course are determined to be critical. For this purpose, science teachers should primarily aim to develop students' motivation and attitudes towards science courses. Courses should be taught considering individual differences, which will in turn increase their performances.

Qualitative researches should be conducted to examine acquired research results, and activities that may positively influence students' motivation and attitudes in courses should be included in order to enable them to be science-literate individuals.

Students' state of attitudes and motivation should be occasionally identified with actual data, not only by researchers but also teachers. Within this framework, courses may be organized so as to allow assessments of motivation and attitudes.

\section{References}

Akbudak, Y. (2005). İlköğretim 7. slnı ögrencilerinin fen bilgisi dersine ve ögretimine ilişsin tutumlart ve önerileri (Yayınlanmamış yüksek lisans tezi). Selçuk Üniversitesi Sosyal Bilimler Enstitüsü, Konya.

Alkan, A. (2006). İlköğretim öğrencilerinin fen bilgisine karşı tutumları (Yayınlanmamış Yüksek Lisans Tezi), Afyon Kocatepe Üniversitesi Sosyal Bilimler Enstitüsü, Afyon.

Azizoğlu, N., \& Çetin, G. (2009). 6. ve 7. sınıf öğrenme stilleri, fen dersine yönelik tutumları ve motivasyonları arasındaki ilişki. Kastamonu Ĕ̈itim Dergisi, 17(1), 171-182.

Baykul, Y. (1990). Illkokul beşinci sınıftan lise ve dengi okulların son sinıflarına kadar matematik ve fen derslerine karşı tutumda görülen değiş̧meler ve öğrenci seçme sinavindaki başarı ile ilişskili olduğu düşünülen bazı faktörler. Ankara: ÖSYM yayınları.

Büyüköztürk, S., Çakmak, E. K., Akgün, Ö. E., Karadeniz, S., \& Demirel, F. (2008). Bilimsel arastirma yöntemleri. Ankara: Pegem Akademi Yayincilik.

Çakır, N. K., Şenler, B., \& Taşkın, B. G. (2007). İlköğretim II. Kademe Öğrencilerinin Fen Bilgisi Dersine Yönelik Tutumlarının Belirlenmesi. Türk Eğitim Bilimleri Dergisi, 5(4), 637-655.

Çepni, S., Ayas, A., Johnson, D., \& Turgut, M. F. (1997). Fizik öğretimi. Ankara: YÖK/Dünya Bankas1 Milli Eğitimi Geliştirme Projesi, Hizmet Öncesi Öğretmen Eğitimi.

Debacker, T. K., \& Nelson, R. M. (2001). Motivation to learn science: Differences related to gender, class type and ability. The Journal of Educational Research, 93(4), 245-255. http://dx.doi.org/10.1080/00220670009598713

Dede, Y., \& Yaman, S. (2008). Fen öğrenmeye yönelik motivasyon ölçeği: Geçerlik ve güvenirlik çalışması. Necatibey Ĕ̈itim Fakültesi Elektronik Fen ve Matematik Eğitimi Dergisi, 2(1), 19-37.

Demir, R., Öztürk, N., \& Dökme, İ. (2012). İlköğretim 7. sınıf öğrencilerinin fen ve teknoloji dersine yönelik motivasyonlarının bazı değişkenler açısından incelenmesi. Mehmet Akif Ersoy Üniversitesi Eğitim Fakültesi Dergisi, 12(23), 1-21.

Erkuş, A. (2003). Ölçme ve Psikometrinin Tarihsel Kökenleri: Güvenirlik Geçerlik ve Madde Analizi. Tutumlar Bileşenleri ve Ölçülmesi. Türk Psikologlar Derneği Yayınları, 24, 34-72.

Ertan, H. (2006). Ortä̈ğretim öğrencilerinin kimya derslerine yönelik güdülenme tür 10. (içsel ve dışsal) ve düzeylerinin bazı değişkenler açısından incelenmesi (Yayınlanmamış Yüksek Lisans Tezi). Balıkesir Üniversitesi Fen Bilimleri Enstitüsü, Balıkesir.

Fraenkel, J. R., \& Wallen, N., E. (2006). How To Design and Evaluate Research in Education. Newyork: Mcgraw-Hill Hieger Education.

George, R. (2000). Measuring change in students' attitudes toward science over time: An application of latent variable growth modeling. Journal of Science Education and Technology, 9(3), 213-225. http://dx.doi.org/10.1023/A:1009491500456

Goldsmith, E. B. (2000). Resource Management for Individuals and Families. Wadsworth Thomson, USA.

Gürkan, T., \& Gökçe, E. (2000, Eylül). İlköğretim öğrencilerinin fen bilgisi dersine yönelik tutumları. IV. Fen Bilimleri 
Ĕ̆itimi Kongresi Bildiri Kitabı, 188-192, Hacettepe, Ankara.

Harlen, W. (1990). Primary Science; Taking The Plunge. London : Heinemann Books.

Hendrickson, A. B. (1997). Predicting student success with the learning and study strategies 14.inventory (LASSI) (Unpublished master's thesis). Iowa State University, Ames, IA. In Shih

İnel, E. D., Kaya, K., \& Mutlu, O. (2014). Ortaokul Öğrencilerinin Fen Öğrenmeye Yönelik Motivasyonlarının Farklı Değişkenlere Göre İncelenmesi: Uşak ili Örneği. Mersin University Journal of the Faculty of Education, 10(1), $13-26$.

Jewett, T. O. (1996). "And They Is Us": Gender Issues in the Instruction of Science. ERIC. ED402202.

Jovanovic, J., \& King, S. S. (1998). Boys And Girls İn The Performance-Based Science Classroom:

Karasar, N. (2003). Bilimsel Araştırma Yöntemi. Ankara: Nobel Yayın Dağıtım.

Kaya, H., \& Böyük, U. (2011). İlköğretim II. kademe öğrencilerinin fen ve teknoloji dersine ve fen deneylerine karş1 tutumlar1. TÜBAV Bilim Dergisi, 4(2), 120-130.

Kenar, İ., \& Balcı, M. (2012). Fen ve teknoloji dersine yönelik tutum ölçeği geliştirme: ilköğretim 4 ve 5 . sınıf örneği. Dumlupinar University Journal of Social Science/Dumlupinar Üniversitesi Sosyal Bilimler Dergisi, 34, 201-210.

Kuyper, H., Van der Werf, M. P. C., \& Lubbers, M. J. (2000). Motivation, meta-cognition and self-regulation as predictors of long term educational attainment. Educational Research and Evaluation,6(3), 181-205. http://dx.doi.org/10.1076/1380-3611(200009)6:3;1-A;FT181

Martin, A. J. (2001). The student motivation scale: A tool for measuring and enhancing motivation. Australian Journal of Guidance and Counselling, 11, 11-20. http://dx.doi.org/10.1017/s1037291100004301

Midgley, C. M., Feldlaufer, H., \& Eccles, J. S. (1989). Student/teacher relations before 13. and after the transition to junior high school, Child Development, 60, 981-992. http://dx.doi.org/10.2307/1131038

Milli, E. B. (2005). İlköğretim fen ve teknoloji dersi öğretim programı ve kılavuzu, Ankara: MEB Yayınc1lık.

Napier, J. D., \& Riley, J. P. (1985). Relationship between affective determinants and achievement in science for seventee-year-olds. Journal of Research in Science Teaching, 22(4), 365-383. http://dx.doi.org/10.1002/tea.3660220407

Osborne, J., Simon, S., \& Collins, S. (2003). Attitudes towards science: A review of the literature and its implications. International journal of science education, 25(9), 1049-1079. http://dx.doi.org/10.1080/0950069032000032199

Özkan, Ş. (2003). The Roles of Motivational Beliefs and Learning Styles on Tenth Grade Students' Biology Achievement (Yayımlanmamış Doktora Tezi). Orta Doğu Teknik Üniversitesi (ODTÜ) Eğitim Bilimleri Enstitüsü, Ankara.

Patrick, A. O., Kpangban, E., \& Chibueze, O. O. (2007). Motivation effects on test scores of senior secondary school science students. Studies on Home and Community Science, 1(1), 57-64.

Pintrich, P. R., Marx, R. W., \& Boyle, R. A. (1993). Beyond cold conceptual change: The role of motivational beliefs and classroom contextual factors in the process of conceptual change. Review of Educational Research, 63(2), 167-199. http://dx.doi.org/10.3102/00346543063002167

Serin, O., \& Mohammadzadeh, B. (2008). The relationship between primary school students' attitudes towards science and their science achievement (sampling: Izmir). Journal of Educational Sciences, 2(6), 68-75.

Shih, C. C., \& Gamon, J. (2001). Web-based learning: Relationships among student motivation, attitude, learning styles and achievement. Journal of Agricultural Education, 42(4), 12-22. http://dx.doi.org/10.5032/jae.2001.04012

Singh, K., Granville, M., \& Dike, S. (2002). Mathematics and science achievement: Effects of motivation, interest, and academic engagement. The Journal of Educational Research, 95(6), 323-332. http://dx.doi.org/10.1080/00220670209596607

Spitzer, D. R. (1996). Motivation: The Neglected Factor in Instructional Design. Educational Technology, 36(3), 45-49.

Türkmen, L. (2002). Sınıf öğretmenliği 1. sınıf öğrencilerinin fen bilimleri ve fen bilgisi öğretimine yönelik tutumları. Hacettepe Üniversitesi Eğitim Fakültesi Dergisi, 23(23), 218-228.

Ülgen, G. (1995). Egitim Psikolojisi-Birey ve Ögrenme. Ankara: Bilim Yayınları.

Uzun, N., \& Keleş, Ö. (2010). Fen öğrenmeye yönelik motivasyonun bazı demografik özelliklere göre değerlendirilmesi. Gazi Ĕ̆itim Fakültesi Dergisi, 30(2), 561-584. 
Who's Doing the Performing? American Educational Research Journal, 35, 477-496. http://dx.doi.org/10.3102/00028312035003477

Wolters, C. A. (1999). The relation between high school students' motivational regulation and their use of learning strategies, effort, and classroom performance. Learning and Individual Differences, 11(3), 281-299. http://dx.doi.org/10.1016/S1041-6080(99)80004-1

Wolters, C. A., \& Rosenthal, H. (2000). The relation between students' motivational beliefs and their use of motivational regulation strategies. International Journal of Educational Research, 33(7), 801-820. http://dx.doi.org/10.1016/S0883-0355(00)00051-3

Yaman, S., \& Öner, F. (2006). İlköğretim Öğrencilerinin Fen Bilgisi Dersine Bakış Açılarını Belirlemeye Yönelik Bir Araştırma. Kastamonu Ĕ̆itim Dergisi, 14(1), 339-346.

Yenice, N., Saydam, G., \& Telli, S. (2012). İlköğretim Öğrencilerinin Fen Öğrenmeye Yönelik Motivasyonlarını Etkileyen Faktörlerin Belirlenmesi. Ahi Evran Üniversitesi Kırşehir Ĕgitim Fakültesi Dergisi, 13(2), $231-247$.

Yılmaz, H., \& Çavaş, P. H. (2007). Reliability and validity study of the students' motivation toward Science Learning (SMTSL) questionnaire. Elementary Education Online, 6(3), 430-440.

This work is licensed under a Creative Commons Attribution 3.0 License. 